\title{
Serum HE4 as a prognostic marker in cervical cancer: a retrospective study
}

\section{Woo Yeon Hwang}

Seoul National University Bundang Hospital https://orcid.org/0000-0003-0231-8330

\section{Dong Hoon Suh}

Seoul National University Bundang Hospital

Kidong Kim

Seoul National University Bundang Hospital

Yong Beom Kim

Seoul National University Bundang Hospital

Jae Hong No ( $\square$ jhno@snu.ac.kr)

Seoul National University Bundang Hospital

\section{Research article}

Keywords: human epididymis protein 4 HE4, cervical cancer, tumor marker, prognosis

Posted Date: October 5th, 2020

DOI: https://doi.org/10.21203/rs.3.rs-75394/v1

License: (c) (i) This work is licensed under a Creative Commons Attribution 4.0 International License. Read Full License 


\section{Abstract \\ Background}

Human epididymis protein 4 (HE4) is a tumor marker that has been well-investigated in ovarian and endometrial cancers. The aim of this study was to evaluate the prognostic value of serum HE4 as a tumor marker in patients with cervical cancer.

\section{Methods}

Serum HE4 levels from 67 cervical cancer patients were measured by immunoassay before starting primary treatment between September 2014 and May 2018. A mean serum HE4 level of 72.6 pmol/L was used to divide the patients into low and high HE4 groups. The patient characteristics, clinicopathological variables, and survival outcomes were compared between the 2 groups.

\section{Results}

There were 55 (82.1\%) patients in the HE4< $72.6 \mathrm{pmol} / \mathrm{L}$ group and 12 (17.9\%) patients in the HE4 > 72.6 pmol/L group at the date of diagnosis. Higher HE4 levels were significantly associated with older age at diagnosis (age < 50: 0.0\% vs. age $\geq 50: 100.0 \%$; $P=0.002$ ), menopause (premenopause: $8.3 \%$ vs. postmenopause: $91.7 \%$; $\mathrm{P}=0.009$ ), higher FIGO stage (stage I-II: $25.0 \%$ vs. III-IV: 75.5\%; $\mathrm{P}=0.008$ ), large tumor size (<4.0cm: $41.7 \%$ vs. $\geq 4.0 \mathrm{~cm}: 58.3 \%$; $\mathrm{P}=0.029$ ), positive lymph node metastasis (negative: $41.7 \%$ vs. positive: $58.3 \%$; $\mathrm{P}=$ 0.049), and involvement of the parametrium (negative: $25.0 \%$ vs. positive: $75.0 \%$; $=0.006$ ). Higher levels of HE4 was a predictive factor for worse overall survival but not for progression-free survival, although elevated HE4 levels were not found to be independent factors for the prediction of either overall survival or progression-free survival. When subgroup analysis was performed by histological type, similar results were obtained for patients with squamous cell carcinoma.

\section{Conclusions}

Our data revealed that high levels of HE4 expression were correlated with poor OS, indicating that elevated HE4 levels are associated with a poor prognosis for patients with cervical cancer.

\section{Background}

Over the past few decades, efforts have been made to reduce the incidence and mortality of cervical cancer through early detection and prevention. Nevertheless, cervical cancer remains the fourth most commonly diagnosed cancer and the fourth leading cause of cancerrelated death in women worldwide (1). Histologically, approximately $80 \%$ of cervical cancer cases are squamous cell carcinoma (SCC) and approximately $20 \%$ are adenocarcinoma (ADC) $(2,3)$. Currently, squamous cell carcinoma antigen (SCC-Ag) and cancer antigen 125 (CA $125)$ are the most commonly used tumor markers for cervical cancer. Increased levels of SCC-Ag are present in only $64 \%$ of patients with SCC and $25 \%$ of patients with ADC, while increased levels of CA125 are present in only $42.6 \%$ of patients with SCC and in $18.9 \%$ of patients with ADC (3). Therefore, the identification of novel markers that improve the detection rate of cervical cancer is required.

Cervical cancer is a preventable disease and its morbidity and mortality has been dramatically reduced by the introduction of cervical cytology (4). However, cervical cytology has low sensitivity and a high false positive rate, partially due to inadequate specimen collection (3, 5). Adjunctive tests such as colposcopy and screening for human papillomavirus (HPV) have been suggested to overcome this low accuracy (6). In addition, tumor markers for the diagnosis and follow up of cervical cancer are necessary. SCC-Ag is the most widely used tumor marker in the diagnosis of cervical cancer. Elevated levels of SCC-Ag are related to tumor size and stage of disease before treatment, as well as to the response to treatment (7). However, the diagnostic sensitivity is only $30 \%$ for early cervical cancer (8). As well, the utility of SCC-Ag in other histologic types is still unclear. With these limitations, identifying other tumor markers for cervical cancer is highly important.

Human epididymis protein 4 (HE4) is a promising biomarker that has been shown to have great potential for clinical use (9-11). HE4 was first isolated from the epithelial cells of the human epididymis and can also be detected in serum (12). HE4 expression has also been identified in a number of normal human tissues outside of the male reproductive system, as well as in various types of malignancies (13, 14). Previous studies have demonstrated that HE4 levels are higher in certain type of cancer (15-17). Increased HE4 is commonly found in tumors of gynecologic origin, and HE4 is well established in ovary and endometrial cancers $(18,19)$. It has been reported that serum HE4, both alone and in combination with CA125, has great potential to predict prognosis (20-22). 
Although it is known that serum levels of HE4 are significantly increased in ovarian and endometrial cancers, research on cervical cancer has been minimal. Some studies have shown that patients affected by cervical cancer may also have higher levels of HE4 (17, 23). However, as these studies were limited by their small sample size, it remains unclear whether HE4 is a valuable marker for cervical cancer. A tumor marker that enables better stratification of patients with cervical cancer may improve individualized primary treatment and would help to prevent over- or under-treatment of these patients. Therefore, we sought to evaluate the prognostic value of serum HE4 as a tumor marker for cervical cancer patients.

\section{Methods}

This retrospective study received approval from the Institutional Review Board of the Seoul National University Bundang Hospital (SNUBH; No. B-1602/336-103) and was performed in accordance with the principles of the Declaration of Helsinki. The requirement for informed consent was waived due to the retrospective nature of the study.

\section{Study population}

We retrospectively reviewed the medical records of 67 cervical cancer patients who were treated at Seoul National University Bundang Hospital, a tertiary hospital in Korea, from September 2014 to May 2018. All patients were restaged based on the revised 2018 International Federation of Gynecology and Obstetrics (FIGO) staging system for cervical cancer (24). We included patients who met the following inclusion criteria: (1) patients who had histologically confirmed cervical cancer of any stage; (2) those who underwent initial treatment, such as radical hysterectomy with lymphadectomy, concurrent chemoradiation therapy, radiation therapy or chemotherapy only; and (3) those who had HE4 levels assessed at diagnosis, before initiation of first treatment. Patients with the following conditions were excluded: (1) patients who had an incomplete treatment for any reason; (2) those who had insufficient clinical and pathological data; and (3) those with other malignancies that had the potential to influence survival outcomes.

For the patients who met the criteria mentioned above, we reviewed the medical records, surgical records, pathological findings, and clinical characteristics. Histology was pathologically evaluated in all patients. Tumor size, lymphovascular space invasion (LVSI), lymph node (LN) metastasis, and involvement of the parametrium were evaluated pathologically only in patients who initially received surgery, while magnetic resonance imaging (MRI), computed tomography (CT), and positron emission tomography computed tomography were evaluated in patients who received initial treatment other than surgery.

\section{HE4 Immunoassay}

The serum HE4 concentration was measured before initiation of patient treatment using the Architect Analyzer (Abbott Laboratories, USA). This is a two-step immunoassay that quantitatively measures HE4 levels in human serum using chemiluminescent microparticle technology. The inter-assay precision for measurement of HE4 was 3.5\% (49.7 pmol/L), 3.6\% (168.1 pmol/L) and 3.8\% (648.2 pmol/L).

\section{Statistical analysis}

The 67 cervical patients had a mean serum HE4 level of $72.6 \mathrm{pmol} / \mathrm{L}$ (standard deviation $=95.0$ ) prior to the initiation of treatment. As no definitive diagnostic thresholds for HE4 have been reported to date, we evaluated the differences in clinicopathological characteristics between patients who had lower HE4 levels ( $<72.6 \mathrm{pmol} / \mathrm{L})$ and those who had higher HE4 levels ( $\geq 72.6 \mathrm{pmol} / \mathrm{L})$ at initial diagnosis.

For comparison of continuous variables, the Student's $t$-test and Mann-Whitney $U$ test were used. Ordinal and categorical variables were analyzed using the Pearson's chi-squared test or Fisher's exact test, as applicable. The association between HE4 levels and the survival outcomes of patients with cervical cancer was assessed by comparing patients with lower HE4 levels ( $<72.6$ pmol/L) and those with higher HE4 levels ( $\geq 72.6 \mathrm{pmol} / \mathrm{L}$ ) before treatment started. Progression-free survival (PFS) and overall survival (OS) rates were calculated by the Kaplan-Meier method and the differences between curves were assessed using the log-rank test. Univariate analysis was performed using the Cox proportional hazards model to evaluate the impact of patient characteristics and clinical factors on survival. For multivariate survival analysis, Cox proportional hazards analysis was used to estimate the prognostic effects of several variables. All analyses were performed using SPSS software for Windows (version 25.0; SPSS Inc., Chicago, IL, USA). P < 0.05 indicated statistical significance.

\section{Results}

In this study, we investigated the HE4 levels in 67 cervical cancer patients. The overall patient characteristics are presented in Table 1. The mean age of the population was $53.4 \pm 13.1$ years. There were $28(41.8 \%)$ premenopausal patients and 39 (58.2\%) postmenopausal patients. The most common histological type was SCC (76.1\%), followed by ADC (17.9\%), adenosquamous cell carcinoma 1 (1.5\%) and others (3.0\%). A total of 40 (50.7\%) patients were stage I, 4 (6.0\%) patients were stage II, $17(25.4 \%)$ patients were stage III, and 6 (9.0\%) 
patients were stage IV. Over half of the patients underwent surgery (67.2\%) for primary treatment, and 29 (43.3\%) had adjuvant treatment after initial therapy regardless of the type of primary treatment. During a median length of observation of 43.8 months (range: $9.23-60.88$ months), 11 patients (16.4\%) experienced disease recurrence and 12 patients (17.9\%) died.

The mean concentration of serum HE4 was used to discriminate between low and high HE4 levels. There were 55 (82.1\%) patients with mean HE4 levels below 72.6 pmol/L and 12 (17.9\%) patients with mean HE4 levels above 72.6 pmol/L at the date of diagnosis. In our analysis, higher HE4 levels were significantly associated with older age ( $\geq 50)$ at diagnosis, menopause, higher FIGO stage, tumor size, presence of LVSI, positive LN metastasis and involvement of the parametrium (Table 2). There was no statistically significant association between HE4 and either adjuvant treatment or recurrence.

Fig. 1 shows the PFS and OS of patients for each group. There was no significant difference in PFS between the two groups (hazard ratio [HR]: 0.650; 95\% confidence interval [CI]: 0.145-2.921; $P=0.572$ ) (Fig. 1A). However, patients with higher HE4 levels had significantly worse OS than those with lower HE4 levels (HR: 3.726; $95 \% \mathrm{Cl}$ : 1.182-11.747; $P=0.016$ ) (Fig. 1B). We also performed subgroup analysis of patients with the SCC histological type $(n=50)$, and the results were consistent with those of the overall study population. There was no significant difference observed in PFS (HR: 0.974; 95\% Cl: 0.198-4.805; $P=0.975)$ (Fig. 1C), but patients with higher HE4 levels were associated with worse OS than those with lower HE4 levels (HR: 5.449; 95\% Cl: 1.460-20.332; $P=0.005)$ (Fig. 1D).

In order to assess the prognostic significance of clinicopathologic variables of PFS and OS, we performed univariate Cox analysis. FIGO stage, tumor size, LN metastasis and involvement of parametrium were identified as unfavorable factor for PFS and OS (Table 3). In addition, higher HE4 levels were significantly associated with poor clinical outcomes for OS (HR: 3.726; 95\% Cl: 1.182-11.747; $P=0.025$; Table 3). On multivariate analysis, higher HE4 levels did not remained as an independent indicator of OS (HR: 1.899; $95 \% \mathrm{Cl}$ : 0.507-7.116; $P=0.342$; Table 3). The results were similar in the subgroup analysis for the SCC histological type. Univariate analysis revealed that high levels of HE4 were associated with poor prognostic factor for OS (HR: 5.449; 95\% Cl: 1.460-20.332; $P=0.012$; Table 4), whereas multivariate analysis revealed that high levels of HE4 did not influence OS (HR: 2.856; 95\% Cl: 0.663-12.294; $P=0.159$; Table 4).

\section{Discussion}

In this study, we found that high expression of HE4 is correlated with poor OS, indicating that HE4 is a potential candidate biomarker for predicting the prognosis of cervical cancer. Several recent studies investigating HE4 have reported that it is an effective tumor marker for predicting prognosis and is associated with poor OS and PFS, especially in ovarian cancer (25). Our findings revealed that, in cervical cancer patients, elevated serum HE4 levels were significantly correlated with FIGO stage as well tumor size, LVSI, LN metastasis, and parametrium involvement, but not with histological type. Moreover, we found that in univariate analysis serum HE4 levels were associated with worse OS. However, HE4 levels were not found to be an independent prognostic factor for PFS. Similar results were observed in the subgroup analysis of patients with histologically confirmed SCC.

Careful attention is required in interpreting serum HE4 levels, as they can be affected by numerous factors (26). Previous studies have shown that age, menopausal status, smoking, renal function, chronic liver disease, ethnicity, and detection method may influence serum HE4 levels $(17,27-29)$. Thus, our results should be interpreted with caution. At current, there is no consensus established for optimal baseline serum HE4 cutoff values (30). Based on previous published investigations, a serum HE4 cut-off value of $70 \mathrm{pmol} / \mathrm{L}$ yields the best sensitivity and specificity (26). The positive serum HE4 cut-off values previously identified in ovarian and endometrial cancer patients were found to be similar to the mean value of HE4 in our study $(23,31)$.

This study has several limitations. First, the existence of underlying selection bias is possible due to the retrospective design. Second, the sample size of the study population as well as the number of recurrence and death events might be insufficient for a comparison of survival outcomes between lower and higher serum levels of HE4. Third, no subgroup analysis was performed for the ADC histology type because of the small sample size of this population. Lastly, we did not attempt any stratification of the study population.

\section{Conclusions}

In conclusion, our study showed that elevated serum HE4 was associated with poor prognostic factors for cervical cancer and was correlated with poor OS, suggesting the potential of HE4 as a novel biomarker for predicting the survival of patients with cervical cancer.

\section{Abbreviations}

HE4

Human Epididymis protein 4 
SCC

Squamous Cell Carcinoma

ADC

Adenocarcinoma

SCC-Ag

Squamous Cell Carcinoma Antigen

CA 125

Cancer Antigen 125

HPV

Human Papillomavirus

FIGO

International Federation of Gynecology and Obstetrics

LVSI

Lymphovascular Space Invasion

LN

Lymph Node

MRI

Magnetic Resonance Imaging

CT

Computed Tomography

PFS

Progression-Free Survival

OS

Overall Survival

HR

Hazard Ratio

\section{Declarations}

\section{ETHICS APPROVAL AND CONSENT TO PARTICIPATE}

The study was conducted in accordance with the Declaration of Helsinki, and the protocol was approved by the Institutional Review Board of the Seoul National University Bundang Hospital. . The requirement for informed consent was waived due to the retrospective nature of the study.

\section{CONSENT FOR PUBLICATION}

Not applicable.

\section{AVAILABILITY OF DATA AND MATERIALS}

The data generated or analysed during this study are available from the corresponding author upon reasonable request.

\section{COMPETING INTERESTS}

The authors declare that they have no conflict of interest.

\section{FUNDING}

The authors have no support or funding to report.

\section{AUTHOR CONTRIBUTIONS}

Conceptualization: WY Hwang, JH No; Methology: WY Hwang, JH No; Data acquisition: WY Hwang; Validation: WY Hwang, JH No; Formal analysis and investigation: all authors; Writing - original draft: WY Hwang; Writing - review \& editing: all authors; Supervision: JH No 
Thanks to all the authors who contributed to this article, and to the publisher for supporting this article.

\section{References}

1. Bray F, Ferlay J, Soerjomataram I, Siegel RL, Torre LA, Jemal A. Global cancer statistics 2018: GLOBOCAN estimates of incidence and mortality worldwide for 36 cancers in 185 countries. CA: A Cancer Journal for Clinicians. 2018;68(6):394-424.

2. Couvreur K, Naert E, De Jaeghere E, Tummers P, Makar A, De Visschere P, et al. Neo-adjuvant treatment of adenocarcinoma and squamous cell carcinoma of the cervix results in significantly different pathological complete response rates. BMC Cancer. 2018;18(1):1101.

3. Laengsri V, Kerdpin U, Plabplueng C, Treeratanapiboon L, Nuchnoi P. Cervical Cancer Markers: Epigenetics and microRNAs. Laboratory medicine. 2018;49(2):97-111.

4. Barut MU, Kale A, Kuyumcuoglu U, Bozkurt M, Agacayak E, Ozekinci S, et al. Analysis of Sensitivity, Specificity, and Positive and Negative Predictive Values of Smear and Colposcopy in Diagnosis of Premalignant and Malignant Cervical Lesions. Medical science monitor: international medical journal of experimental clinical research. 2015;21:3860-7.

5. Boone JD, Erickson BK, Huh WK. New insights into cervical cancer screening. Journal of gynecologic oncology. 2012;23(4):282-7.

6. Lim SC, Yoo CW. Current Status of and Perspectives on Cervical Cancer Screening in Korea. Journal of pathology translational medicine. 2019;53(4):210-6.

7. Fu J, Wang W, Wang Y, Liu C, Wang P. The role of squamous cell carcinoma antigen (SCC Ag) in outcome prediction after concurrent chemoradiotherapy and treatment decisions for patients with cervical cancer. Radiation oncology (London England). 2019;14(1):146.

8. Molina R, Filella X, Augé JM, Bosch E, Torne A, Pahisa J, et al. CYFRA 21.1 in patients with cervical cancer: comparison with SCC and CEA. Anticancer research. 2005;25(3a):1765-71.

9. Manganaro L, Michienzi S, Vinci V, Falzarano R, Saldari M, Granato T, et al. Serum HE4 levels combined with CE CT imaging improve the management of monitoring women affected by epithelial ovarian cancer. Oncol Rep. 2013;30(5):2481-7.

10. Nassir M, Guan J, Luketina H, Siepmann T, Rohr I, Richter R, et al. The role of HE4 for prediction of recurrence in epithelial ovarian cancer patients-results from the OVCAD study. Tumour biology: the journal of the International Society for Oncodevelopmental Biology Medicine. 2016;37(3):3009-16.

11. Kumarasamy C, Madhav MR, Sabarimurugan S, Lakhotiya K, Pandey V, Priyadharshini T, et al. Diagnostic and prognostic role of HE4 expression in multiple carcinomas: A protocol for systematic review and meta-analysis. Medicine. 2019;98(28):e15336.

12. Kirchhoff C, Habben I, Ivell R, Krull N. A Major Human Epididymis-Specific cDNA Encodes a Protein with Sequence Homology to Extracellular Proteinase Inhibitors1. Biol Reprod. 1991;45(2):350-7.

13. Bingle L, Singleton V, Bingle CD. The putative ovarian tumour marker gene HE4 (WFDC2), is expressed in normal tissues and undergoes complex alternative splicing to yield multiple protein isoforms. Oncogene. 2002;21(17):2768-73.

14. Galgano MT, Hampton GM, Frierson HF. Jr. Comprehensive analysis of HE4 expression in normal and malignant human tissues. Modern pathology: an official journal of the United States Canadian Academy of Pathology Inc. 2006;19(6):847-53.

15. Cymbaluk-Ploska A, Chudecka-Glaz A, Pius-Sadowska E, Sompolska-Rzechula A, Machalinski B, Surowiec A, et al. Clinical importance of serum HE4 and MMP2 levels in endometrial cancer patients. OncoTargets therapy. 2017;10:3169-75.

16. Saarelainen SK, Peltonen N, Lehtimaki T, Perheentupa A, Vuento MH, Maenpaa JU. Predictive value of serum human epididymis protein 4 and cancer antigen 125 concentrations in endometrial carcinoma. American journal of obstetrics gynecology. 2013;209(2):142.e1-6.

17. Molina R, Escudero JM, Auge JM, Filella X, Foj L, Torne A, et al. HE4 a novel tumour marker for ovarian cancer: comparison with CA 125 and ROMA algorithm in patients with gynaecological diseases. Tumour biology: the journal of the International Society for Oncodevelopmental Biology Medicine. 2011;32(6):1087-95.

18. Grisaru D, Hauspy J, Prasad M, Albert M, Murphy KJ, Covens A, et al. Microarray expression identification of differentially expressed genes in serous epithelial ovarian cancer compared with bulk normal ovarian tissue and ovarian surface scrapings. Oncol Rep. 2007;18(6):1347-56.

19. Drapkin R, von Horsten HH, Lin Y, Mok SC, Crum CP, Welch WR, et al. Human epididymis protein 4 (HE4) is a secreted glycoprotein that is overexpressed by serous and endometrioid ovarian carcinomas. Cancer research. 2005;65(6):2162-9.

20. Kalapotharakos G, Asciutto C, Henic E, Casslén B, Borgfeldt C. High preoperative blood levels of HE4 predicts poor prognosis in patients with ovarian cancer. Journal of Ovarian Research. 2012;5(1):20.

21. Mutz-Dehbalaie I, Egle D, Fessler S, Hubalek M, Fiegl H, Marth C, et al. HE4 is an independent prognostic marker in endometrial cancer patients. Gynecol Oncol. 2012;126(2):186-91. 
22. Hellström I, Raycraft J, Hayden-Ledbetter M, Ledbetter JA, Schummer M, Mclntosh M, et al. The HE4 (WFDC2) Protein Is a Biomarker for Ovarian Carcinoma. 2003;63(13):3695-700.

23. Montagnana M, Lippi G, Ruzzenente O, Bresciani V, Danese E, Scevarolli S, et al. The utility of serum human epididymis protein 4 (HE4) in patients with a pelvic mass. Journal of clinical laboratory analysis. 2009;23(5):331-5.

24. Bhatla N, Aoki D, Sharma DN, Sankaranarayanan R. Cancer of the cervix uteri. International Journal of Gynecology Obstetrics. 2018;143(S2):22-36.

25. Yuan C, Li R, Yan S, Kong B. Prognostic value of HE4 in patients with ovarian cancer. Clinical chemistry laboratory medicine. 2018;56(7):1026-34.

26. Simmons AR, Baggerly K, Bast RC. Jr. The emerging role of HE4 in the evaluation of epithelial ovarian and endometrial carcinomas. Oncology (Williston Park NY). 2013;27(6):548-56.

27. Tian Y, Wang C, Cheng L, Zhang A, Liu W, Guo L, et al. Determination of reference intervals of serum levels of human epididymis protein 4 (HE4) in Chinese women. Journal of Ovarian Research. 2015;8(1):72.

28. Moore RG, McMeekin DS, Brown AK, DiSilvestro P, Miller MC, Allard WJ, et al. A novel multiple marker bioassay utilizing HE4 and CA125 for the prediction of ovarian cancer in patients with a pelvic mass. Gynecol Oncol. 2009;112(1):40-6.

29. Moore RG, Miller MC, Eklund EE, Lu KH, Bast RC Jr, Lambert-Messerlian G. Serum levels of the ovarian cancer biomarker HE4 are decreased in pregnancy and increase with age. American journal of obstetrics gynecology. 2012;206(4):349.e1-7.

30. Karlsen NS, Karlsen MA, Høgdall CK, Høgdall EV. HE4 tissue expression and serum HE4 levels in healthy individuals and patients with benign or malignant tumors: a systematic review. Cancer epidemiology, biomarkers \& prevention: a publication of the American Association for Cancer Research, cosponsored by the American Society of Preventive Oncology. 2014;23(11):2285-95.

31. Huhtinen K, Suvitie P, Hiissa J, Junnila J, Huvila J, Kujari H, et al. Serum HE4 concentration differentiates malignant ovarian tumours from ovarian endometriotic cysts. British journal of cancer. 2009;100(8):1315-9.

\section{Tables}

Table 1. Characteristics of the overall study population $(N=67)$ 


\begin{tabular}{|ll|}
\hline Characteristics & N(\%) \\
\hline Age, years & $53.4 \pm 13.2$ \\
\hline Mean \pm SD & \\
\hline Menopause & $28(41.8)$ \\
\hline Premenopause & $39(58.2)$ \\
\hline Postmenopause & \\
\hline Histology & $50(74.6)$ \\
\hline Squamous cell carcinoma & $15(22.4)$ \\
\hline Adenocarcinoma & $1(1.5)$ \\
\hline Adenosquamous cell carcinoma & $1(1.5)$ \\
\hline Others & \\
\hline FIGO Stage & $40(59.7)$ \\
\hline I & $4(6.0)$ \\
\hline II & $17(25.4)$ \\
\hline III & $6(9.0)$ \\
\hline IV & \\
\hline Initial Treatment & $45(67.2)$ \\
\hline Operation & $16(23.9)$ \\
\hline CCRT & $2(3.0)$ \\
\hline RTx & $4(6.0)$ \\
\hline CTx & $38(56.7)$ \\
\hline Adjuvant Treatment & \\
\hline Yes & \\
\hline No & \\
\hline Recurrence & \\
\hline Yes & \\
\hline No & \\
\hline
\end{tabular}

Abbreviations: SD, standard deviation; FIGO, International Federation of Gynecology and Obstetrics; CCRT, concurrent chemoradiation therapy; RTx, Radiation therapy; CTx, Chemotherapy

Table 2. Distribution of study population according to levels of HE4 


\begin{tabular}{|c|c|c|c|}
\hline Chararcteristics & $\begin{array}{l}\mathrm{HE} 4<72.6 \mathrm{pmol} / \mathrm{L} \\
(\mathrm{N}=55)\end{array}$ & $\begin{array}{l}\mathrm{HE} 4 \geq 72.6 \mathrm{pmol} / \mathrm{L} \\
(\mathrm{N}=12)\end{array}$ & $P$ value \\
\hline Age, years & & & $0.002^{\star}$ \\
\hline$<50$ & $26(47.3)$ & $0(0.0)$ & \\
\hline$\geq 50$ & $29(52.7)$ & $12(100.0)$ & \\
\hline Menopause & & & $0.010 *$ \\
\hline Yes & $28(50.9)$ & $11(91.7)$ & \\
\hline No & $27(49.1)$ & $1(8.3)$ & \\
\hline Histology & & & $0.270 *$ \\
\hline SCC & $39(70.9)$ & $11(91.7)$ & \\
\hline Non-SCC & $16(29.1)$ & $1(8.3)$ & \\
\hline FIGO Stage & & & $0.017 *$ \\
\hline$|-| \mid$ & $40(72.7)$ & $4(33.3)$ & \\
\hline III-IV & $15(27.3)$ & $8(66.7)$ & \\
\hline Tumor size, cm & & & $0.029 *$ \\
\hline$<4.0$ & $43(78.2)$ & $5(41.7)$ & \\
\hline$\geq 4.0$ & $12(21.8)$ & $7(58.3)$ & \\
\hline LVSI & & & $0.004^{\star \star}$ \\
\hline Negative & $25(45.5)$ & $2(16.7)$ & \\
\hline Positive & $17(30.9)$ & $1(8.3)$ & \\
\hline Unknown & $13(23.6)$ & $9(75.0)$ & \\
\hline LN metastasis & & & $0.049 *$ \\
\hline Negative & $40(72.7)$ & $5(41.7)$ & \\
\hline Positive & $15(27.3)$ & $7(58.3)$ & \\
\hline PM involvement & & & $0.006^{*}$ \\
\hline Negative & $40(72.7)$ & $3(25.0)$ & \\
\hline Positive & $15(27.3)$ & $9(75.0)$ & \\
\hline Adjuvant Treatment & & & 0.604 \\
\hline Yes & $23(41.8)$ & $6(50.0)$ & \\
\hline No & $32(58.2)$ & $6(50.0)$ & \\
\hline Recurrence & & & $0.721 *$ \\
\hline Yes & $13(23.6)$ & $2(16.7)$ & \\
\hline No & $42(76.4)$ & 10 (83.3) & \\
\hline
\end{tabular}

Abbreviations: HE4, human epididymis protein 4; SCC, squamous cell caricinoma; FIGO, International Federation of Gynecology and Obstetrics; LVSI, lymphovascular space invasion; LN, lymph node; PM, parametrium

*P values were calculated by Fisher's exact test.

Table 3. Factors associated with survival in the overall population 


\begin{tabular}{|c|c|c|c|c|c|c|c|c|c|c|c|c|}
\hline \multirow[t]{3}{*}{ Variables } & \multicolumn{6}{|c|}{ Progression-free survival } & \multicolumn{6}{|c|}{ Overall survival } \\
\hline & \multicolumn{3}{|c|}{ Univariate analysis } & \multicolumn{3}{|c|}{ Multivariate analysis } & \multicolumn{3}{|c|}{ Univariate analysis } & \multicolumn{3}{|c|}{ Multivariate analysis } \\
\hline & $\mathrm{HR}$ & $95 \% \mathrm{Cl}$ & $\begin{array}{l}P \\
\text { value }\end{array}$ & $\mathrm{HR}$ & $95 \% \mathrm{Cl}$ & $\begin{array}{l}P \\
\text { value }\end{array}$ & $\mathrm{HR}$ & $95 \% \mathrm{Cl}$ & $\begin{array}{l}P \\
\text { value }\end{array}$ & $\mathrm{HR}$ & $95 \% \mathrm{Cl}$ & $\begin{array}{l}P \\
\text { value }\end{array}$ \\
\hline Age & & & 0.115 & & & & & & 0.054 & & & \\
\hline$<50$ & 1 & & & & & & 1 & & & & & \\
\hline$\geq 50$ & 2.770 & $\begin{array}{l}0.781- \\
9.819\end{array}$ & & & & & 7.491 & $\begin{array}{l}0.967- \\
58.038\end{array}$ & & & & \\
\hline $\begin{array}{l}\text { Histologic } \\
\text { type }\end{array}$ & & & 0.141 & & & & & & 0.944 & & & \\
\hline Non-SCC & 1 & & & & & & 1 & & & & & \\
\hline SCC & 0.459 & $\begin{array}{l}0.163- \\
1.294\end{array}$ & & & & & 0.954 & $\begin{array}{l}0.258- \\
3.525\end{array}$ & & & & \\
\hline FIGO stage & & & 0.002 & & & & & & 0.001 & & & \\
\hline $\mid-I I$ & 1 & & & & & & 1 & & & & & \\
\hline III-IV & 6.475 & $\begin{array}{l}2.037- \\
20.576\end{array}$ & & & & & 11.875 & $\begin{array}{l}2.595- \\
54.334\end{array}$ & & & & \\
\hline Tumor size & & & 0.014 & & & 0.246 & & & 0.001 & & & 0.014 \\
\hline$<4.0 \mathrm{~cm}$ & 1 & & & 1 & & & 1 & & & 1 & & \\
\hline$\geq 4.0 \mathrm{~cm}$ & 3.603 & $\begin{array}{l}1.301- \\
9.981\end{array}$ & & 1.980 & $\begin{array}{l}0.624- \\
6.285\end{array}$ & & 9.738 & $\begin{array}{l}2.619- \\
36.201\end{array}$ & & 7.035 & $\begin{array}{l}1.489- \\
33.227\end{array}$ & \\
\hline $\begin{array}{l}\mathrm{LN} \\
\text { metastasis }\end{array}$ & & & 0.001 & & & 0.017 & & & 0.011 & & & 0.370 \\
\hline No & 1 & & & 1 & & & 1 & & & 1 & & \\
\hline Yes & 6.516 & $\begin{array}{l}2.054- \\
20.669\end{array}$ & & 5.337 & $\begin{array}{l}1.349- \\
21.111\end{array}$ & & 4.707 & $\begin{array}{l}1.416- \\
15.650\end{array}$ & & 1.975 & $\begin{array}{l}0.446- \\
8.743\end{array}$ & \\
\hline $\begin{array}{l}\text { PM } \\
\text { involvement }\end{array}$ & & & 0.031 & & & 0.869 & & & 0.019 & & & 0.800 \\
\hline No & 1 & & & 1 & & & 1 & & & 1 & & \\
\hline Yes & 3.144 & $\begin{array}{l}1.113- \\
8.879\end{array}$ & & 0.898 & $\begin{array}{l}0.249- \\
3.236\end{array}$ & & 4.213 & $\begin{array}{l}1.267- \\
14.010\end{array}$ & & 0.804 & $\begin{array}{l}0.149- \\
4.344\end{array}$ & \\
\hline HE4 & & & 0.575 & & & & & & 0.025 & & & 0.342 \\
\hline$<72.6$ & 1 & & & & & & 1 & & & 1 & & \\
\hline$\geq 72.6$ & 0.650 & $\begin{array}{l}0.145- \\
2.921\end{array}$ & & & & & 3.726 & $\begin{array}{l}1.182- \\
11.747\end{array}$ & & 1.899 & $\begin{array}{l}0.507- \\
7.116\end{array}$ & \\
\hline
\end{tabular}

Abbreviations: HR, hazard ratio; Cl, confidence interval; SCC, squamous cell caricinoma; FIGO, International Federation of Gynecology and Obstetrics; LN, lymph node; PM, parametrium; HE4, human epididymis protein 4

Table 4. Factors associated with survival in patients with squamous cell carcinoma 


\begin{tabular}{|c|c|c|c|c|c|c|c|c|c|c|c|c|}
\hline \multirow[t]{3}{*}{ Variables } & \multicolumn{6}{|c|}{ Progression-free survival } & \multicolumn{6}{|c|}{ Overall survival } \\
\hline & \multicolumn{3}{|c|}{ Univariate analysis } & \multicolumn{3}{|c|}{ Multivariate analysis } & \multicolumn{3}{|c|}{ Univariate analysis } & \multicolumn{3}{|c|}{ Multivariate analysis } \\
\hline & $\mathrm{HR}$ & $95 \% \mathrm{Cl}$ & $\begin{array}{l}P \\
\text { value }\end{array}$ & $\mathrm{HR}$ & $95 \% \mathrm{Cl}$ & $\begin{array}{l}P \\
\text { value }\end{array}$ & $\mathrm{HR}$ & $95 \% \mathrm{Cl}$ & $\begin{array}{l}P \\
\text { value }\end{array}$ & $\mathrm{HR}$ & $95 \% \mathrm{Cl}$ & $\begin{array}{l}P \\
\text { value }\end{array}$ \\
\hline Age & & & 0.115 & & & & & & 0.181 & & & \\
\hline$<50$ & 1 & & & & & & 1 & & & & & \\
\hline$\geq 50$ & 5.324 & $\begin{array}{l}0.665- \\
42.615\end{array}$ & & & & & 44.538 & $\begin{array}{l}0.171- \\
11630.901\end{array}$ & & & & \\
\hline FIGO stage & & & 0.018 & & & 0.021 & & & 0.007 & & & 0.033 \\
\hline$|-| I$ & 1 & & & 1 & 1 & & 1 & & & 1 & & \\
\hline III-IV & 6.846 & $\begin{array}{l}1.393- \\
33.642\end{array}$ & & 18.476 & $\begin{array}{l}1.561- \\
218.736\end{array}$ & & 17.443 & $\begin{array}{l}21.178- \\
139.673\end{array}$ & & 20.833 & $\begin{array}{l}1.287- \\
337.164\end{array}$ & \\
\hline Tumor size & & & 0.103 & & & & & & 0.001 & & & 0.098 \\
\hline$<4.0 \mathrm{~cm}$ & 1 & & & & & & 1 & & & 1 & & \\
\hline$\geq 4.0 \mathrm{~cm}$ & 3.009 & $\begin{array}{l}0.801- \\
11.297\end{array}$ & & & & & 14.755 & $\begin{array}{l}3.045- \\
71.493\end{array}$ & & 4.577 & $\begin{array}{l}0.753- \\
27.801\end{array}$ & \\
\hline $\begin{array}{l}\mathrm{LN} \\
\text { metastasis }\end{array}$ & & & 0.046 & & & 0.329 & & & 0.027 & & & 0.148 \\
\hline No & 1 & & & 1 & & & & & & 1 & & \\
\hline Yes & 4.203 & $\begin{array}{l}1.024- \\
17.260\end{array}$ & & 0.334 & $\begin{array}{l}0.037- \\
3.014\end{array}$ & & 4.801 & $\begin{array}{l}1.200- \\
19.212\end{array}$ & & 0.251 & $\begin{array}{l}0.039- \\
1.629\end{array}$ & \\
\hline $\begin{array}{l}\text { PM } \\
\text { involvement }\end{array}$ & & & 0.256 & & & & & & 0.061 & & & \\
\hline No & 1 & & & & & & 1 & & & & & \\
\hline Yes & 2.159 & $\begin{array}{l}0.573- \\
8.142\end{array}$ & & & & & 3.756 & $\begin{array}{l}0.939- \\
15.031\end{array}$ & & & & \\
\hline HE4 & & & 0.975 & & & & & & 0.012 & & & 0.159 \\
\hline$<72.6$ & 1 & & & & & & 1 & & & 1 & & \\
\hline$\geq 72.6$ & 1.026 & $\begin{array}{l}0.208- \\
5.060\end{array}$ & & & & & 5.449 & $\begin{array}{l}1.460- \\
20.332\end{array}$ & & 2.856 & $\begin{array}{l}0.663- \\
12.294\end{array}$ & \\
\hline
\end{tabular}

Abbreviations: HR, hazard ratio; Cl, confidence interval; FIGO, International Federation of Gynecology and Obstetrics; LN, lymph node; PM, parametrium; HE4, human epididymis protein 4

\section{Figures}


A

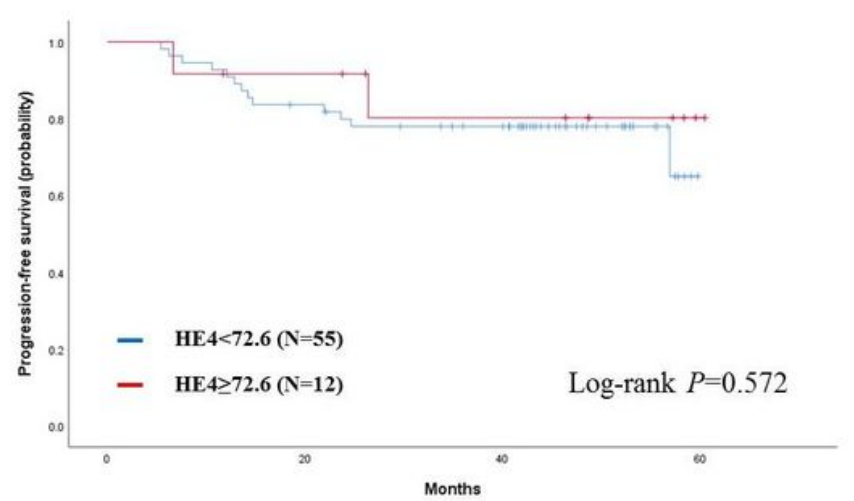

C

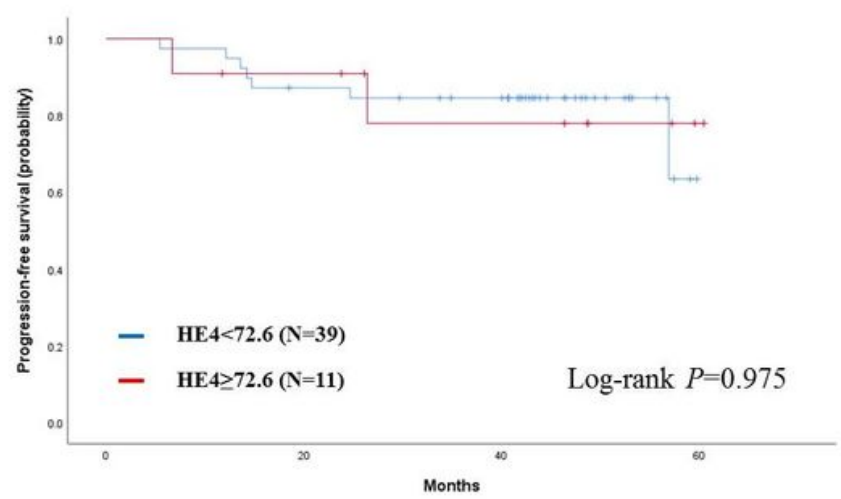

B

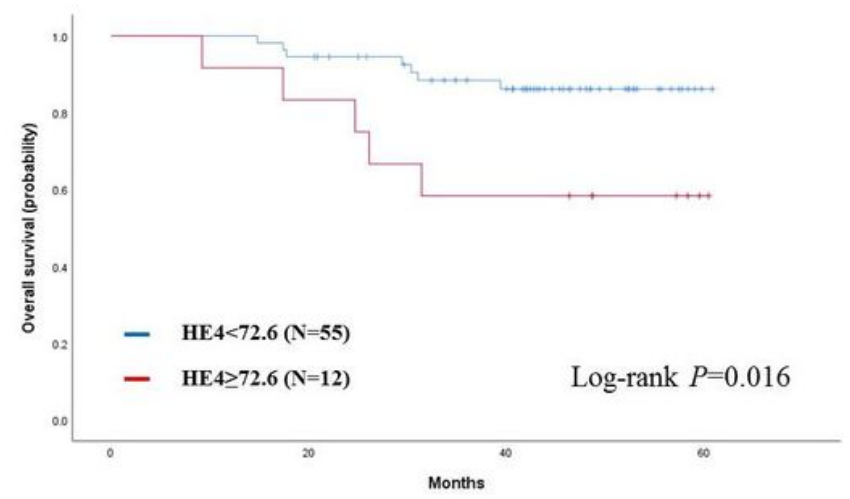

D

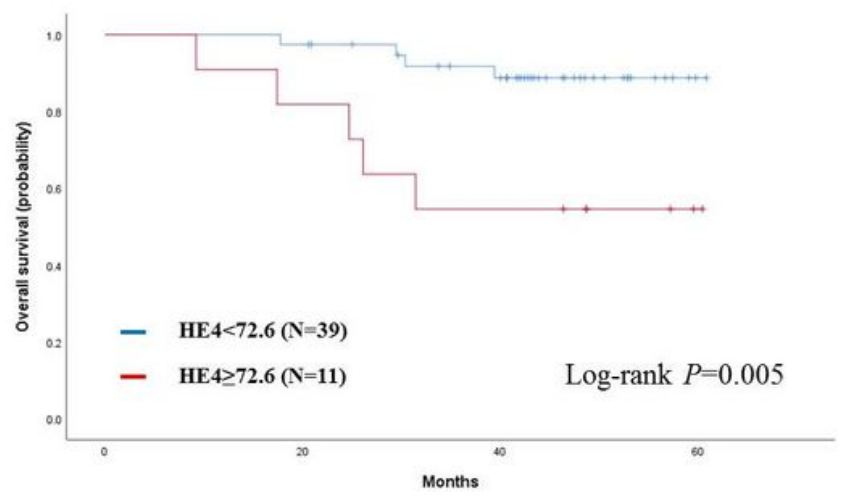

\section{Figure 1}

Comparisons of survival outcomes between patients with low $(<72.6 \mathrm{pmol} / \mathrm{L})$ and high ( $\geq 72.6 \mathrm{pmol} / \mathrm{L}) \mathrm{HE}$. (A) Progression-free survival in the entire cohort; (B) Overall survival in the entire cohort; (C) Progression-free survival in patients with squamous cell carcinoma; (D) Overall survival in patients with squamous cell carcinoma. 